\title{
Perspektif Aksiologi Terhadap Penurunan Minat Belajar Anak di Masa Pandemi
}

\author{
Theresia Endang Sulistyawati \\ Sekolah Tinggi Teologi Injili Indonesia Madiun, Jawa Timur \\ Email : tresiahosea88@gmail.com
}

\begin{abstract}
School education is usually carried out in a school complex which is an ideal meeting place between educators and students in realizing the quality of quality education. ducation contains values of moral ethics, aesthetics and social care to achieve educational success. But that changed when learning activities began to be carried out at home online. All parties began to make various very difficult adaptations. The school and educators must work hard to strive for an adequate internet network as a means of learning. Students and parents at home are struggling to take part in online learning. After this has been implemented, it is known that there are many obstacles faced by various parties. A very sad case is the decline in children's interest in learning. In this study the authors used a qualitative method to describe the problems that occurred. The results of the data collection, it is known that there is a decrease in children's interest in learning and laziness in learning, it is that efforts to motivate can encourage children's enthusiasm for learning. The purpose of this research is to implement ethical values and social care in social life. The conclusion is; a decrease in children's interest in learning (laziness) in the perspective of axiology is a bad value and behavior is not praiseworthy for whatever reason.
\end{abstract}

Keywords : laziness, challenge, motivation.

\begin{abstract}
Abstrak
Kegiatan pembelajaran lazimnya dilakukan dalam komplek sekolah yang menjadi tempat pertemuan ideal antara pendidik dan peserta didik dalam mewujudkan mutu pendidikan yang berkualitas. Pendidikan mengandung nilai-nilai etika, moral, estetika dan kepedulian sosial untuk mencapai keberhasilan pendidikan. Namun menjadi berubah ketika kegiatan pembelajaran mulai beralih dilakukan di rumah secara daring. Semua pihak mulai melakukan berbagai adaptasi yang sangat menyulitkan. Pihak sekolah dan pendidik harus bekerja keras untuk mengupayakan jaringan internet yang memadai sebagai sarana pembelajaran. Siswa dan orang tua di rumah berjuang agar dapat mengikuti pembelajaran daring. Setelah terlaksana, diketahui banyak kendala yang dihadapi berbagai pihak. Kasus yang sangat menyedihkan adalah terjadinya penurunan minat belajar anak. Dalam penelitian ini penulis menggunakan metode kualitatif untuk mendeskripsikan permasalahan yang terjadi. Hasil dari pengumpulan data yang dilakukan, diketahui adanya penurunan minat belajar anak dan kemalasan belajar, upaya memotivasi mampu mendorong kembali semangat belajar anak. Tujuan penelitian ini untuk mengimplementasikan nilai-nilai etika, kepedulian sosial dalam kehidupan bersosialisasi. Kesimpulannya adalah; penurunan minat belajar anak (kemalasan) dalam perspektif aksiologi merupakan nilai keburukan dan perilaku tidak terpuji, apapun alsannya.
\end{abstract}

Kata Kunci : kemalasan, tantangan, motivasi. 


\section{PENDAHULUAN}

Kegiatan belajar atau pembelajaran merupakan suatu proses panjang yang dilakukan setiap manusia untuk mencapai suatu hasil menjadi lebih baik, sehingga diperlukan strategi pembelajaran yang tepat. Oleh sebab itu diperlukan suatu cara yang menarik dan tepat dalam program pembelajaran terhadap anak didik. Dengan bantuan media elektronik masa kini banyak membantu anak didik dalam hal mengumpulkan berbagai informasi tambahan yang diperlukan dalam pembuatan tugas belajar. Namun kemajuan tidak selamanya membawa berkah atau menguntungkan bagi siswa. ${ }^{1}$ Kenyataan yang timbul adanya berbagai kendala yang menyebabkan persoalan baru dengan kecenderungan penurunan minat belajar anak. Fakta menunjukkan bahwa terjadinya penurunan minat belajar anak terjadi saat diberlakukan pembelajaran daring secara masal.

Berdasarkan pada pernyataan yang dikeluarkan oleh Badan Kesehatan Dunia WHO pada bulan Maret 2020, bahwa Corona Virus menjadi pandemic global, maka kegiatan belajar mengajar menjadi salah satu kegiatan yang terdampak. WHO secara resmi mengumumkan wabah virus corona (COVID-19) sebagai pandemic"Ini adalah pandemi pertama yang disebabkan oleh corona virus. Dalam dua minggu terakhir jumlah kasus COVID-19 telah meningkat 13 kali lipat, dan jumlah negara yang terkena dampak telah meningkat tiga kali lipat. Karena itu kami telah membuat penilaian bahwa COVID-19 dapat dikategorikan sebagai pandemic."2 Konfirmasi update BNPB_Indonesia, 7-9-

\footnotetext{
${ }^{1}$ Abuddin Nata, Manajemen Pendidikan, Jakata: Kencana, 2008

2 Rehia Sebayang, CNBC Indonesia 12 March 2020. WHO Resmi Tetapkan Corona Pandemi,
}

2020 mencatat adanya peningkatan kasus Covid 19 yang masih tinggi. Penyebaran virus corona di Indonesia ini tersebar dalam 34 provinsi di Indonesia, sehingga perlu diberlakukan pembatasan social untuk memutus rantai penyebaran Covid 19. ${ }^{3}$ Pembelajaran adalah suatu kegiatan yang dapat memberikan informasi dan pengetahuan dalam interaksi yang berlangsung antara pendidik dengan peserta didik. Pembelajaran konvensional yang berlaku selama ini, umumnya lebih mudah dimengerti oleh siswa, selain memberikan kemudahan belajar adanya interaksi langsung tanpa kendala apapun sehingga belajar konvensional merupakan cara strategi pembelajaran.

Dengan kasus pandemi saat ini, maka pemerintah Indonesia mengambil kebijakan memberlakukan pembelajaran daring sebagai upaya pemutusan rantai penyebaran virus corona di kalangan masyarakat. Pembelajaran daring yang ditetapkan pemerintah, ditujukan kepada seluruh jenjang pendidikan dari TK hingga perguruan tinggi. Alternatif ini berkaitan dengan berkembangnya revolusi industri 4.0 yang sangat berpengaruh pada terlaksananya berbagai kegiatan daring. Sistem kerja atau belajar daring akan mengeliminasi waktu dan jarak dengan bantuan platform digital berbasis internet yang mampu menunjang pembelajaran tanpa adanya interaksi fisik antara pendidik dan peserta didik. Kondisi saat ini menunjukkan bahwa pembelajaran daring yang dilakukan dirumah dengan bimbingan orang tua, memiliki banyak kendala sehingga tidak sedikit orang tua

\footnotetext{
https://www.cnbcindonesia.com/news/ diakses 15 September 2020.

${ }^{3}$ Rohmana Kurniandari. UPDATE

Sebaran Virus Corona Indonesia.

https://ternate.tribunnews.com/2020/09/07/u pdate, diakses 15 september 2020.
} 
yang meminta pihak sekolah untuk segera melaksanakan pembelajaran tatap muka. ${ }^{4}$

Mengetahui kesulitan belajar dari rumah, penyebab menurunnya minat belajar anak. Meliputi kurangnya pemahaman materi oleh orang tua, kesulitan menumbuhkan minat belajar anak, tidak memiliki cukup waktu untuk mendampingi anak karena harus bekerja, orang tua tidak sabar dalam mendampingi dan membantu anak belajar dirumah, kesulitan dalam mengoperasikan gadget, dan kendala terkait jangkauan layanan internet. Dalam pelaksanaannya, orang tua memiliki banyak kesulitan dengan pembelajaran daring. ${ }^{5}$ Lemahnya motivasi belajar akan berpengaruh pada melemahnya prestasi yang dicapai anak didik. Ciri-ciri anak didik yang kurang memiliki motivasi belajar adalah: a) Tidak antusias dalam belajar, b) Lebih senang berada diluar kelas atau membolos, c) Cepat merasa bosan d) Mengantuk, e) Pasif. Minat belajar yang rendah menyebabkan rendahnya pencapaian skor keberhasilan dalam belajar sehingga akan merendahkan prestasi belajar siswa. Menurunnya motivasi belajar atau minat belajar, sangat besar dipengaruhi oleh cara pembelajaran online itu sendiri. Proses konekting ke jaringan internet yang sulit, tidak semua masyarakat bisa mengoperasikannya, menyebabkan pembelajaran online menjadi sangat sulit untuk diikuti siswa. Pada akhirnya memunculkan kebosanan, kemalasan bahkan patah semangat, sehingga

4 Putra, R. \& Irwansyah, I. Media

Komunikasi Digital, Efektif Namun Tidak Efisien, Studi Media Richness Theory dalam Pembelajran Jarak Jauh Berbasis Teknologi di Masa Pandemi. Jurnal Ilmu Sosial dan Politik, Vol 1, no 2, 2020, 1-13.

5 Anita Wardani, Yulia Ayriza. Analisis Kendala Orang Tua dalam Mendampingi Anak Belajar di Rumah Pada Masa Pandemi Covid-19. pembelajaran tetap dilakukan atas dasar keterpaksaan untuk memperoleh nilai.

Salah satu upaya mengatasi masalah adalah dengan memperbaiki kualitas pembelajaran adalah dengan mengubah metode pembelajarannya menjadi mudah dan menyenangkan. Sehingga siswa diharapkan dapat mengikuti proses pembelajaran dengan baik. Metode pembelajaran yang diduga dapat meningkatkan keaktifan dan hasil belajar siswa pada berbagai bidang studi. Guru merupakan faktor paling dominan yang menentukan kualitas pembelajaran. Kualitas pembelajaran yang baik, akan menghasilkan hasil belajar yang baik pula. Guru disini berperan sebagai fasilitator, memberi informasi yang autentik, valid, mengarahkan permasalahan, memberikan instruksi atau perintah yang disesuaikan dengan daya pikir anak sehingga dapat menyelesaikan permasalahan, fokus pada tujuan pencapaian kompetensi. Hasil belajar merupakan representasi pencapaian kompetensi siswa yang nantinya berguna saat siswa melanjutkan ke sekolah yang lebih tinggi. ${ }^{6}$ Dalam menyelesaikan masalah penurunan minat belajar anak, maka perlu adanya motivasi yang muncul terutama dari diri sendiri, orang tua, guru dan lingkungan. Secara garis besar definisi motivasi mengandung makna: Motivasi adalah suatu perubahan energi yang terdapat dalam diri sendiri yang mendorong untuk melakukan sesuatu yang akan dicapai, yang mendorong setiap individu melakukan dan menyelesaikan tugas-tugas akademik. ${ }^{7}$

Jurnal Obsesi: Jurnal Pendidikan Anak Usia Dini Vol 5 no 1, 2020, 772-782

${ }^{6}$ Bekti, Wulandari. Pengaruh Problem

Based Learning Terhadap Hasil Belajar, Ditinjau

Dari Motivasi Belajar PLD di SMK. Jurnal

Pendidikan Vokasi, Vol 3 no 2, 2013, 178-190.

${ }^{7}$ Woolfolk, Anita. Educational

psychology. Boston: Pearson, 2007. 
Memanfaatkan penggunaan media dengan baik, membuat belajar daring dengan cara yang menarik dan menyenangkan, perlu disertai permainan animasi lucu-lucu, atau candaan menarik agar tidak membosankan dalam penyampaian materi pelajaran. Memaksimalkan fasilitas pembelajaran yang menunjang seperti internet, computer atau gawai. Pemanfaatan fasilitas yang baik akan memaksimalkan proses kegiatan belajar, pihak sekolah diharapkan memberikan dukungan optimal untuk pembelajaran online.

\section{METODE}

Penulisan penelitian ini adalah kualitatif, dalam penelitian ini menggunakan studi literatur, yaitu dalam mengumpulkan informasi data yang relevan diambil dari berbagai sumber kepustakaan seperti; buku, jurnal, berita, internet yang sesuai dengan topik pembahasan, untuk dapat mendeskripsikan hasil kajian permasalahan. Menurut ahli; penelitian kepustakaan merupakan kajian teoritis, referensi serta literatur ilmiah yang berkaitan dengan nilai dan perkembangan pada situasi sosial yang diteliti. ${ }^{8}$ Dalam uji validitas penulis menggunakan mode triangulasi sumber data, analisis berupa; a) pengumpulan data; b) reduksi data; c) Kesimpulan. Penelitian kualitatif digunakan untuk menyelidiki, menemukan, menggambarkan, dan menjelaskan permasalahan yang terjadi. ${ }^{9}$ Penelitian kualitatif adalah penelitian yang menghasilkan data deskriptif berupa kata-kata tertulis atau lisan dari perilaku yang dapat diamati dengan maksud

\footnotetext{
${ }^{8}$ Sugiyono. Metode Penelitian Kuantitatif Kualitatif. Bandung: Alfabeta, 2012.

${ }^{9}$ Miles, Matthew B, A. Michael Huberman. Qualitative Data Analysis. Jakarta: terjemahan UI Press, 2005.
}

memahami fenomena yang sedag terjadi seperti perilaku, persepsi, motivasi, tindakan, dengan cara deskripsi dalam bentuk kata-kata dan bahasa. ${ }^{10}$

\section{HASIL DAN PEMBAHASAN}

\section{A. Hasil Penelitian}

1.Penulis menentukan empat puluh orang partisipan terdiri dari siswa dan orang tua, untuk mengetahui seberapa banyak tingkat penurunan minat belajar anak.

Tingkat SD 15 orang, SMP 15 Orang, (mewakili dari 3 tempat kelompok belajar atau Bimbel), dan Orang tua 10 Orang. Permasalahan yang dihadapi anak: 1) Sukar, tidak bisa mengikuti belajar online. 2) Terlalu banyak tugas dan tidak dimengerti. 3) Kesulitan menghubungi guru untuk bertanya. 4) Belajar asal-asalan untuk (yang penting) dapat nilai raport. 5) Tidak ada dukungan keluarga dalam belajar. 6) Bersikap apatis, masa bodoh, malas, enggan belajar.

Permasalah yang dihadapi orang tua: 1) Menambah berat pekerjaan orang tua di rumah. 2) lebih banyak keluar beaya (lebih boros). 3) Kesibukan, tidak bisa membantu belajar anak. 4) Ketidakmengertian dalam pelajaran dan internet. 5) Keputusasaan, tidak mau membantu belajar anak (akhirnya bersikap masa bodoh).

2. Mengetahui seberapa banyak anak yang mengalami penurunan minat belajar, dapat terlihat dari alasan dan harapan serta keinginan.

Anak yang mengalami penurunan minat belajar: SD 6 orang, SMP 9 orang. Anak yang masih rajin belajar: SD 9 orang, SMP 5 orang.

\footnotetext{
10 Lexy J. Moleong. Metodologi
} Penelitian Kualitatif. Bandung: Remaja Rosdakarya, 2010. 
Alasan anak: 1) Ingin segera kembali ke sekolah. 2) Di sekolah lebih mudan belajar, bisa pada bertanya guru dan teman, banyak teman, bisa bermain dan belajar bersama, dapat berkumpul teman. 3) Di sekolah bebas berinteraksi dan bergaul. 4) Lebih menyenangkan, menyemangatkan, bisa melihat banyak teman setiap hari.

Alasan orang tua: 1) Kembali ke sekolah. 2) Orangtua sudah membayar mahal untuk beaya sekolah dan mempercayakan anak pada sekolah, jika belajar daring berarti mengeluarkan beaya lebih besar, artinya ini jauh lebih boros dan merepotkan. 3) Meringankan pekerjaan orang tua di rumah.

Keterangan: 1) Siswa SMP dan orang tua lebih memilih kembali ke sekolah. 2) Belajar daring merepotkan, menyulitkan, menyita kesibukan orang tua. 3) Keinginan untuk selalu berinteraksi.

\section{Kesimpulan dari hasil analisa diatas} adalah :

1) Orang tua mengijinkan anak untuk kembali belajar bersama di sekolah, atau dalam suatu kelompok belajar dengan tetap memperhatikan protokol kesehatan, menjaga jarak duduk anak. 2) Anak kembali bersemangat dalam belajar bersama, senang bertemu teman-teman, karena beberapa bulan terakhir anak seolah terkurung dalam rumah. 3) Anak menjadi lebih mandiri dan tidak sepenuhnya mengganggu aktivitas, kegiatan orang tua di rumah.

\section{b. Pembahasan}

\section{Terminologi Aksiologi}

Kata aksiologi berasal dari kata Yunani yaitu; axion (acion): nilai, norma dan logos (logos): ilmu, pengetahuan. Jadi pengertian aksiologi adalah teori yang

11 Praja, Juhaya S. Aliran-aliran Filsafat dan Etika. Bandung: Yayasan Piara,1997.

12 Adib A. Filsafat Ilmu. Yogyakarta:

Pustaka Pelajar, 2010. mempelajari tentang suatu nilai, hakikat tertinggi pada realita (value) serta etika yang berlaku, dalam perspektif filsafat. ${ }^{11}$ Aksiologi adalah teori tentang nilai, karena didalamnya terkandung nilai-nilai sebagai dasar normative dalam suatu pemanfaatan ilmu pengetahuan dan teknologi. Aksiologi adalah cabang filsafat mengenai orientasi suatu nilai kehidupan. Aksiologi disebut juga teori nilai, dapat menjadi sarana dalam menjawab suatu pertanyaan yang muncul dari sebuah peristiwa yang berkaitan dengan permasalahan atau pengalaman yang terjadi sebagi suatu respon. ${ }^{12}$

Aksiologi menurut Suriasumantri; menyatakan bahwa aksiologi adalah teori yang berkaitan dengan kegunaan dari pengetahuan yang diperoleh, serta menujukkan kaidah-kaidah yang harus perhatikan dalam menerapkan ilmu menjadi hal yang praktis. Aksiologi memuat pemikiran tentang nilai, termasuk nilai moral, nilai Pendidikan, nilai agama, estetika yang dapat menjawab pertanyaan tentang pengetahuan dan keberadaan, yang berkaitan antara teknik procedural dengan operasionalitas metode ilmiah. ${ }^{13}$ Aksiologi merupakan ilmu pendidikan yang menguji dan mengintegrasikan semua nilai tersebut dalam kehidupan manusia serta menjaga, membinanya bagi kepribadian manusia. Bahwa masalah utama adalah kesusilaan, menjadi hakikat yang-baik, senantiasa menarik banyak kalangan, dipandang bersifat hakiki penting untuk dapat mengenal manusia lebih baik. Aksiologi adalah ilmu pengetahuan yang menyelidiki hakikat

13 Suriasumantri, Jujun S. Filsafat Ilmu: Sebuah Pengantar Populer. Jakarta: PT Penebar Swadaya, 2010. 
nilai tertinggi jika ditinjau dari sudut kefilsafatan. ${ }^{14}$

\section{Latar Belakang Pemberlakuan Pembelajaran Daring}

Wabah Corona virus telah menyebabkan penyakit, dari gejala ringan sampai berat. Corona virus yang diketahui menyebabkan penyakit berat seperti Middle East Respiratory Syndrome (MERS) dan Severe Acute Respiratory Syndrome (SARS). COVID-19 merupakan jenis penyakit baru yang belum teridentifikasi sebelumnya. Gelaja umum infeksi COVID-19: gangguan pernapasan akut seperti demam, batuk, dan sesak napas. Masa inkubasi sekitar 6 hari sampai 14 hari. ${ }^{15}$ Dampak dari penyebaran virus corona sangat terasa pada perekonomian, dan dunia pendidikan. Langkah awal yang dilakukan pemerintah Indonesia dalam upaya pencegahan penyemabaran virus yaitu dengan meliburkan kegiatan belajar mengajar (sekolah). Oleh sebab itu pemerintah dan lembaga terkait menghadirkan alternatif proses pendidikan bagi anak peserta didik dengan belajar daring.

Wabah Covid-19 yang melanda 215 negara di dunia, melatarbelakangi terjadinya perubahan metode Pendidikan dari konvesional (tatap muka) menjadi daring. Kondisi ini merupakan tantangan sangat berat bagi dunia pendidikan, khususnya anak usia SD dan SMP. Satuan Tugas Penanganan COVID-19 Indonesia mengumumkan situasi pandemi corona di Indonesia saat ini mengkhawatirkan. Indonesia belum sepenuhnya berhasil menghentikan penularan pandemi virus

\footnotetext{
14 Soejono Soe Margono. Pengantar

Filsafat. Yogyakarta: Tiara Wacana, 1986

15 Yurianto, Ahmad, Bambang Wibowo.

Pedoman Pencegahan Dan Pengendalian COVID

19. (Listiana Azizah, Adistikah Aqmarina, ed.), 2020.
}

corona covid-19. Artinya; pemerintah dan masyarakat sebenarnya belum berhasil menekan dan mencegah penularan tingkat Nasional secara konsisten. Menjadi tugas Bersama, pemerintah dan juga masyarakat agar patuh menerapkan kedisiplinan protokol kesehatan, baik individu maupun kolektif. Kondisi pandemic di Indonesia saat ini sudah mengkhawatirkan, diketahui jumlah pasien baru terkonfirmasi positif covid-19 di Indonesia mencatatkan rekor tertinggi. ${ }^{16}$ Maka di sini dianggap sangat perlu untuk diberlakukan pembelajaran jarak jauh (daring) untuk mncegas penularan Covid-19.

\section{Dasar Pembelajaran Daring; Sekaligus Sebagai Bentuk Pembatasan Sosial}

Dunia Pendidikan termasuk salah satu Lembaga yang terdampak pandemic Covid 19, sangat memprihatinkan. Surat Edaran Kementerian Pendidikan dan Kebudayaan tahun 2020, menjadi dasar diberlakukannya mode pembelajaran dari rumah (online). Menteri Pendidikan Nadiem Anwar Makarim menerbitkan Surat Edaran Nomor 3 Tahun 2020 pada Satuan Pendidikan dan Nomor 36962/MPK.A/HK/2020 tentang Pelaksanaan Pendidikan dalam Masa Darurat Coronavirus Disease (COVID-19), maka kegaiatan belajar dilakukan secara daring (online), dalam upaya pencegahan penyebaran COVID0-19 (Menteri Pendidikan, 2020). Pandemi COVID-19 membuat kegiatan belajar mengajar yang semula dilaksanakan di sekolah kini melalui daring. Pembelajaran daring tentunya dilakukan dengan menyesuaikan kemampuan masing-maisng sekolah.

16

https://www.suara.com/news/2020/09/03/16 2842/pengumuman-situasi-pandemi-coronaindonesia-mengkhawatirkan, diakses 23 September 2020. 
Dengan menggunakan teknologi digital seperti google classroom, zoom, video converence, atau live chat. Kegiatan ini dilakukan dengan pemberian tugas melalui pemantauan, pendampingan oleh guru, bahkan adanya peran serta orang tua dalam membantu terselenggaranya proses belajar daring. ${ }^{17}$

Kementerian Pendidikan dan Kebudayaan (Kemendikbud) menerbitkan Surat Edaran Nomor 15 Tahun 2020 tentang Pedoman Penyelenggaraan Belajar Dari Rumah Dalam Masa Darurat Penyebaran Covid-19. Staf Ahli Menteri Pendidikan dan Kebudayaan Bidang Regulasi, Chatarina Muliana Girsang menyampaikan Surat Edaran Nomor 15 ini untuk memperkuat Surat Edaran Mendikbud Nomor 4 Tahun 2020 tentang Pelaksanaan Pendidikan Dalam Masa Darurat Coronavirus Disease (Covid-19). Saat ini layanan pembelajaran masih mengikuti SE Mendikbud nomor 4 tahun 2020 yang diperkuat dengan SE Sesjen nomor 15 tahun 2020 tentang Pedoman Pelaksanaan BDR selama darurat Covid19, Kamis (28/05/2020). Dalam SE disebutkan bahwa tujuan dari pelaksanaan Belajar Dari Rumah adalah memastikan pemenuhan hak peserta didik untuk mendapatkan layanan pendidikan selama darurat Covid-19, melindungi warga satuan pendidikan dari dampak buruk Covid-19, mencegah penyebaran dan penularan Covid-19 di satuan pendidikan dan memastikan pemenuhan dukungan psikososial bagi pendidik, peserta didik, dan orang tua. ${ }^{18}$

17 Wahyu Aji Fatma Dewi. Dampak Covid-19 Terhadap Implementasi Pembelajaran Daring di Sekolah Dasar. Edukatif: Jurnal Ilmu Pendidikan Vol 2 No 1 April 2020, Univ Kristen Satya Wacana, 55-60

18 Kemendikbud Terbitkan Pedoman Penyelenggaraan Belajar dari Rumah. https://www.kemdikbud.go.id/main/blog/2020
Pademi covid-19 telah mengganggu proses pembelajaran secara konvensional, diperlukan solusi untuk menjawab permasalahan tersebut. Pembelajaran secara daring adalah salah satu alternatif yang dapat mengatasi masalah tersebut. Pembelajaran daring merupakan perilaku pembatasan social (social distancing) dan meminimalisir keramaian atau berkumpul di sekolah, sehingga dianggap dapat mengurangi potensi penyebaran Covid-19 pada kluster anak sekolah. ${ }^{19}$ Dengan pembatasan seperti ini mengakibatkan jauhnya interaksi sosial seorang anak dengan teman-teman di sekolah, serta guru-guru, bahkan hilangnya waktu untuk belajar dan bermain bersama.

\section{Minat Belajar Anak Dalam Pembelajaran Daring}

Melalui pembelajaran virtual atau daring yang tidak terbatas oleh ruang dan waktu membuat interaksi guru dan anak didik dapat dilakukan kapan dan di mana saja atau sewakt-waktu. Metode pembelajaran jarak jauh memang tidak seefektif pembelajaran tatap muka (konvensional). Dalam pelaksanaanya terdapat banyak tantangan, hambatan. Ini harus dikaji secara mendalam pada proses pembelajaran karena dapat menurunkan minat belajar anak. Konsep belajar dari rumah belum sepenuhnya bisa dipraktikkan oleh murid dan guru. Selain itu, para orang tua siswa mengeluhkan banyaknya tugas yang diberikan oleh guru kepada siswa, sehingga menambah beban kerja orangtua, tidak sedikit orang tua yang mengeluhkan cara belajar daring.

/05/kemendikbud-terbitkan-pedomanpenyelenggaraan-belajar-dari-rumah, $29 \mathrm{Mei}$ 2020, diakses 25 September 2020.

${ }^{19}$ Ali Sadikin, Afreni Hamidah. Pembelajaran Daring di Tengah Wabah Covid19. BIODIK: Jurnal Ilmiah Pendidikan Biologi. Vol 6, No 02, 2020. $214-224$ 
Kondisi ini membuat anak semakin stres karena ketidakmampuan menangkap pelajaran yang disampaikan serta tambahan tugas yang harus dikerjakan setia haari. Guru bidang studi memberikan tugas, dengan cara pengerjaan yang rumit dan bertele-tele dengan berbagai praktik tugas. Kondisi ini memaksa anak untuk berusaha sekeras mungkin, kemudian mengakibatkan kelelahan bahkan keputusasaan sehingga enggan untuk belajar dengan sungguh-sungguh. ${ }^{20}$

Menurunnya minat belajar siswa diakibatkan beberapa factor: faktor internal yaitu faktor yang berasal dari dalam (diri sendiri, keluarga), faktor eksternal yaitu faktor yang berasal dari luar (lingkungan, tidak pemahami materi, jaringan internet yang buruk, kuota internet yang tidak mencukupi, kondisi cuaca atau daerah tempat tinggal). Akibat dari perilaku siswa yang mengalami penurunan minat belajar sangat berdampak pada penurunan nilai yang dicapainya. Baik berupa nilai raport, nilainilai pendidikan, nilai kepedulian. Teori belajar behaviorisme menjelaskan bahwa belajar adalah perubahan prilaku yang dapat di amati, diukur dan dinilai secara kongret. Perubahan terjadi melalui ransangan (stimulus) yang menimbulkan hubungan prilaku reaktif (respon) interal maupun eksternal.

\section{Mengatasi Problematika Belajar Daring}

\section{A. Mengetahui faktor penyebab menurunnya minat belajar.}

Hal ini dapat terlihat dari beberapa hal seperti: 1) Pembelajaran daring dinilai kurang efektif dibanding kelas konvensional, karena sulitnya jangkauan internet; seperti daerah pinggiran kota yang sulit mendapatkan sinyal internet, pedesaan, daerah pelosok, yang sama sekali tidak terjangkau oleh internet, mahalnya biaya kuota untuk dapat terintegrasi online. 2) Rendahnya motivasi dan dukungan orang tua membantu anak menyelesaikan tugastugas belajar; ketidakpahaman, kesibukan, kebingungan orang tua akan menambah beban anak dalam belajar. 3) Keterbatasan waktu online, sinyal yang buruk, kehabisan kuota, bahkan disebut sebagai pemborosan karena membelanjakan kuota yang cukup mahal setiap bulannya, serta berbagai gangguan teknis selalu menjadi hambatan, sehingga pembelajaran menjadi tidak maksimal. Kesemuanya ini merupakan pemicu anak menjadi malas, stress, bahkan terjadi penurunan minat belajar, sehingga anak bosan dan tidak lagi peduli pada kegiatan belajar tersebut.

\section{B. Mengatasi Persoalan.}

Tidak semua sekolah siap dalam menerapkan metode pembelajaran daring tersebut. Karena banyak sekolah yang baru pertama kali menerapkan hal semacam itu dan kurangnya fasilitas bagi guru dan peserta didik di daaerah tertentu. Maka dari itu pembelajaran daring mengalami pro dan kontra. Sebagai contoh; pada awal penerapannya, dalam pembelajaran (perkuliahan) daring banyak peserta didik yang menanggapi kelas daring ini dengan baik, namun setelah berjalannya proses pembelajaran (perkuliahan), maka banyak peserta didik justru mengalami kesulitan dalam belajar. Keadaan ini justru menurunkan mutu pembelajaran bagi para peserta didik, serta menurunnya mutu pengajar. Lebih sulit belajar dari rumah, karena situasi dan kondisi yang tidak kondusif. Pikiran jadi buyar, susah fokus, hilangnya konsentrasi, bukan hanya tugas lebih menumpuk, tapi juga banyak distraction saat sedang belajar, berdasarkan pengalaman siswa dalam belajar daring. 
Sehingga para orang tua menghendaki untuk diadakan proses belajar di sekolah. Salah satu faktor yang dapat membangun fokus belajar ada pada dorongan kesenangan dan keteraturan. Kesenangan yaitu melakukan sesuatu yang disukai atau digemari, dapat memadukan belajar daring dengan sedikit game di online agar tidak membosankan. Keteraturan dapat dilakukan dengan jadwal yaang teratur, tidak sembarang waktu agar anak dapat mengetahui jadwal saat harus belajar daring, seperti halnya jadwal rutinitas di sekolah. ${ }^{21}$

C. Meningkatkan kemandirian belajar, minat dan motivasi, keberanian mengemukakan gagasan.

Motivasi adalah hasrat, dorongan dan kebutuhan seseorang untuk dapat melakukan aktivitas tertentu yang dapat meningkatkan gairah belajar atau bekerja. Sehingga motivasi diartikan sebagai kekuatan atau dorongan untuk mencapai tujuan tertentu yaitu pemahaman materi dan pengembangan belajar. Selain itu, motivasi juga merupakan penggerak yang membuat seseorang akan tertarik kepada belajar sehingga berkeinginan untuk belajar secara terus-menerus. ${ }^{22}$

\section{URAIKAN PULA IMPLIKASI HASIL PENELITIAN BAIK TEORITIS MAUPUN PENERAPAN.}

Implikasi aksiologi dalam dunia pendidikan adalah menguji dan mengintegrasikan nilai tersebut dalam kehidupan manusia dan membinanya dalam kepribadian peserta didik. Bukanlah hal yang mudah untuk menyatakan bahwa

\footnotetext{
${ }^{21}$ By editorial kompas. Hambatan dan

Solusi Saat Belajar Daring, APR 10, 2020 https://muda.kompas.id/2020/04/10/hambatandan-solusi-saat-belajar-daring-dari-rumah/ diakses 17 September 2020.

${ }^{22}$ Novianti, N. R. Kontribusi pengelolaan laboratorium dan motivasi belajar siswa terhadap
}

sesuatu itu benar atau salah, baik atau buruk. Melainkan adanya proses pembinaan kepribadian dan mentalitas anak dalam proses belajar. Pendidik harus memberikan pemahaman atau pengertian mengenai apa yang baik, benar, bagus, buruk, boleh dilakukan atau tidak, kepada peserta didik secara komprehensif. Tanpa mengesampingkan estetika dan nilai social dalam masyarakat yang terintegrasi dan saling berkaitan, yang diperlukan dalam dunia Pendidikan. ${ }^{23}$

Implementasi pendekatan obyektifisme logis adalah nyata dalam menentukan tujuan akhir, tujuan tertinggi, dan tujuan umum pendidikan. Para pendidik mempunyai kesadaran akademis bahwa, pengoptimalan operasional pendidikan di sekolah sangat penting, dalam pelaksanaan pendidikan secara nyata, nilai-nilai tujuan tertinggi terletak pada konsep manusia terdidik. Manusia terdidik ialah orang yang peduli pada diri sendiri dan orang lain, dalam berbuat kebaikan. Orang yang mampu bertindak dengan baik dan benar, bermoral baik, bersikap adil, toleran, dapat mengatasi konflik dengan baik dan mandiri merupakan bentuk implementasi orang-orang terdidik. ${ }^{24} \quad$ Pembelajaran daring mengandung nilai etika dan kepedulian. Nilai etika berupa: upaya pencegahan penularan corona virus dapat diminimalisir. Nilai kepedulian: peduli pada kesehatan diri sendiri berarti juga peduli pada kesehatan orang lain, dengan tidak memaksakan diri untuk setiap hari melakukan sekolah konvensional. Tatap muka dapat dilakukan secara berkala, misalnya seminggu hanya sehari sampai dua hari sekolah. Dengan

efektivitas proses pembelajaran. Jurnal Pendidikan MIPA. Edisi khusus 1, 2011, 158-166.

${ }^{23}$ Fithriani. Implikasi Aksiologi Dalam Filsafat Pendidikan. Jurnal- ar raniry, file://C:/Users/User/Downloads/4359-9130-1PB\%20(30.pdf2019, diakses 20 September 2020.

${ }^{24}$ John White. The Aims of Education Restated. London: Routledge \& Kegan Paul, 1982, 87-88. 
tetap memperhatikan protokol kesehatan, menjaga jarak duduk, tidak bergerombol atau berpegangan satu sama lainnya dan sebagainya. Semuanya dapat diimplementasikan dalam kegiatan belajar daring. Nilai sosialitas anak dapat berlangsung saat melakukan interaksi sekolah konvensional, namun dengan memperhatikan dan menjalankan protokol kesehatan dengan baik.

\section{KESIMPULAN}

Perspektif aksiologi terhadap minat belajar anak pada masa pandemi adalah menurun, menjadi kurang baik bahkan terjadi penurunan nilai-nilai yang terkandung dalam aksiologis, disebabkan karena berbagai faktor, ini merupakan nilai keburukan. Nilai kebaikannya adalah; meminimalisir penyebaran corona virus pada anak sekolah, mengajar anak untuk memahami internet. Kemalasan dan ketidakmandirian dalam belajar telah terjadi selama pandemi corona, disadari atau tidak, kondisi ini telah mempengaruhi pola hidup anak.

\section{DAFTAR PUSTAKA}

Abuddin Nata, Manajemen Pendidikan. Jakata: Kencana, 2008.

Adib A. Filsafat Ilmu. Yogyakarta: Pustaka Pelajar, 2010.

Ali Sadikin, Afreni Hamidah. Pembelajaran Daring di Tengah Wabah Covid-19. BIODIK: Jurnal Ilmiah Pendidikan Biologi. Vol 6, No 02, 2020, $214-224$.

Anita Wardani, Yulia Ayriza. Analisis Kendala Orang Tua dalam Mendampingi Anak Belajar di Rumah Pada Masa Pandemi Covid-19. Jurnal Obsesi: Jurnal Pendidikan Anak Usia Dini Vol 5 no 1, 2020, 772-782.

Bekti, Wulandari. Pengaruh Problem Based Learning Terhadap Hasil Belajar, Ditinjau DariMotivasi Belajar PLD di
SMK. Jurnal Pendidikan Vokasi, Vol 3 no 2, 2013, 178-190.

Margono, Soejono Soe. Pengantar Filsafat. Yogyakarta: Tiara Wacana, 1986

Miles, Matthew B, A. Michael Huberman. Qualitative Data Analysis. Jakarta: terjemahan UI Press, 2005.

Moleong, Lexy J. Metodologi Penelitian Kualitatif. Bandung: Remaja Rosdakarya, 2010.

Novianti, N. R. Kontribusi pengelolaan laboratorium dan motivasi belajar siswa terhadap efektivitas proses pembelajaran. Jurnal Pendidikan MIPA. Edisi khusus 1, 2011, 158-166.

Putra, R. \& Irwansyah, I. Media Komunikasi Digital, Efektif Namun Tidak Efisien, Studi Media Richness Theory dalam Pembelajran Jarak Jauh Berbasis Teknologi di Masa Pandemi. Jurnal IImu Sosial dan Politik, Vol 1 no 2, 2020, 1-13.

Praja, Juhaya S. Aliran-aliran Filsafat dan Etika. Bandung: Yayasan Piara,1997.

Sugiyono. Metode Penelitian Kuantitatif Kualitatif. Bandung: Alfabeta, 2012.

Suriasumantri, Jujun S. Filsafat Ilmu: Sebuah Pengantar Populer. Jakarta: PT Penebar Swadaya, 2010.

Suryani, Widyasih. Psikologi Ibu dan Anak. Yogyakarta: Citramaya, 2010.

Wahyu Aji Fatma Dewi. Dampak Covid-19 Terhadap Implementasi Pembelajaran Daring di Sekolah Dasar. Edukatif: Jurnal Ilmu Pendidikan Vol 2 No 1 April 2020, Univ Kristen Satya Wacana, 55-60

Woolfolk, Anita. Educational Psychology. Boston: Pearson, 2007. 
Aksiologi : Jurnal Pendidikan dan Ilmu Sosial Volume : 1 No.1 2020

White, John. The Aims of Education Restated. London: Routledge \& Kegan Paul, 1982, 87-88.

Yurianto, Ahmad, Bambang Wibowo, K. P. Pedoman Pencegahan Dan Pengendalian COVID 19. (Listiana Azizah, Adistikah Aqmarina, ed.), 2020.

By editorial kompas. Hambatan dan Solusi Saat Belajar Daring, APR 10, 2020 https://muda.kompas.id/2020/04/10/ hambatan-dan-solusi-saat-belajardaring-dari-rumah/ diakses 17 September 2020.

Fithriani. Implikasi Aksiologi Dalam Filsafat

Pendidikan. Jurnal- ar raniry, file://C:/Users/User/Downloads/435 9-9130-1-PB\%20(30.pdf2019, diakses 20 September 2020.
Kemendikbud Terbitkan Pedoman Penyelenggaraan Belajar dari Rumah. https://www.kemdikbud.go.id/main/b $\log / 2020 / 05 /$ kemendikbud-terbitkanpedoman-penyelenggaraan-belajardari-rumah, 29 Mei 2020, diakses 25 September 2020.

Rehia Sebayang, CNBC Indonesia 12 March 2020. WHO Resmi Tetapkan Corona Pandemi, https://www.cnbcindonesia.com/new s/ diakses 15 September 2020.

Rohmana Kurniandari. UPDATE Sebaran Virus Corona Indonesia. https://ternate.tribunnews.com/2020 /09/07/update, diakses 15 September 2020. 